\title{
THE STRUCTURE AND METHODS OF GRUPPE 6 E FROM GERMAN SECRET SERVICE DURING THE SECOND WORLD WAR
}

\author{
Marian ZIDARU \\ "Andrei Saguna" University, Constanta, Romania \\ marian.zidaru@yahoo.com
}

\begin{abstract}
In this paper I present the general background picture of the development of Gruppe (group) 6 E from German Secret Service. As a result, for the personal interest of Ernst Kaltenbrunner in the work of the Gruppe, $6 E$ developed a working basis which differs from the normal functioning of the other Laendergruppen (groups of countries), a tendency which became more marked after the transfer of the central office from Berlin to Vienna in 1943. A liaison officer only remained in Berlin. This paper presents the final structure of the Gruppe and the leading personnel, and it is under this final organization that the work of the Gruppe in the Balkan States. The Gruppe maintained liaison officers with the Herman Neubacher and Altenberg Dienststellen (Altenberg offices), these liaison officers being directly subordinated to the Gruppenleiter (Group leader). In common with the outside offices, with which he kept in personal contact, and an Auswerter (analyst) responsible for the evaluation and dissemination of information. The Referate (Abstrat) conducted their operation through the Hauptbeauftragte (Chief Comissioner) working in the various countries under suitable cover.
\end{abstract}

\section{Keywords: Referate, Kaltenbrunner, Balkan states, Gruppe 6 E}

\section{The Origins}

The Sicherheitsdienst (SD-Security Service) was created in 1933 by Reinhard Heydrich as the intelligence service of the NSDAP (Nazi Party). In the early stage the SD did not operate completely independently of the party as its early functions tended to overlap with those of other sections in the party, which did not welcome its creation. The following account therefore of the development of SD activities tends to be misleadingly simplified, and this factor should be borne in mind. It is only at a much later date that the SD as an Intelligence service became clearly defined and separated from the other activities of the Nazis parties. By 1934 Heinz Jost, later to become Amstchef (chief of office) VI, had been given the task of setting up what became Abteilung (Department) VI of the SD-HaupamtanAbteilung (Haupamtan Department) whose function was essentially a security one and was concerned solely with the security of German industry. In this capacity it worked in close collaboration with Abteilung (Department) III of the Abwehr (German Military Intelligence) and with the Gestapoamt (Gestapo Office). The Abteilung developed gradually, and by 1937 became, in the reorganization of the SD-Hauptamt (main office from SD), Amt (Office) III. The new Amt III was itself subdivided into three section of which Abteilung (Department) III/3 contained the germ of the subsequent Amt (office) VI of the RSHA (Reich Main Security Office).

\section{The Development of the Work of Abteilung III/3}

Amt III functioned in its early stages through the then existing SD organization of Oberabschnitte and its subordinate formations throughout Germany. The development of its work was most marked in Eastern Europe where it gradually 
assumed a more positive role in German industry acting latterly as a positive espionage service as against security Service, and was able to provide the SDHauptamt (SD-main Office) with a fairly picture of the German industry and its productive capacity. This development of Amt (office) III work was a general one throughout Germany but in the East a further line of development was taking place as early as 1937 . The Oberabschnitte (Upper sections), in Eastern Germany began to act as collecting centers of information on political trends in those countries sharing a common frontier in Germany but in the East, especially Czechoslovakia and Austria, where the large pro-German minority groups served as a source of information the constant passage backwards and forwards across the frontiers.

It was these two tendencies in the work of Abteilung (Department) III/3, its ability to act as an espionage rather than a security service, and the readiness with which it could extend its could extend its interest from Heydrich to the extent of instructed Jost to prepare the foundation Abteilung III/3. In this Jost was merely given his general conception being that Jost should exploit to establish good contacts in business circles and to develop the facilities which the Oberabschnitte near the German frontier provided for espionage activities outsides the Reich.

The factor however which had been chiefly instrumental in influencing Heydrich's decision to attempt Auslandsnachrichtendienst (Foreign intelligence service) was the part played by the SD in the Anscluss (annexation) with Austria in March 1938. The role of the SD was a prominent one, though the direction of its activities had be from a very much higher level than Jost as Leiter (leader) of Abteilung III/3. The SD had functioned as the liaison between the underground Nazi Party in Austria and the governmental authorities in Germany, but the importance of the Anschluss to the future of the SD was that it represented the first offensive operation undertaken by it, and the significance of this success was not lost on Reinhard Heydrich. Equally important, though the importance was not immediately apparent, was the effect of the Anchluss (Austria Annexation) on the subsequent history of Gruppe (group) VI E. Prominent among the figures who had played a leading part in the underground movement in Austria prior to the Anschluss were Ernst Kaltenbrunner and Hermman Neubacher, both of whom were to be closely identified with the work of VI E subsequent to Heydrich late in 1942. In addition, the SDLeitabschnitt (SD-guide section) which was set up in Vienna immediately after the Anschluss had among its personnel some offices who were to become leading members of VIE. It was in fact the Anschluss which gave birth to the 'Austrian Group' which was to play an important part in the subsequent history not only of Gruppe (group) VI E, but in the development and dissolution of Amt (office) VI.

The fundamental change of policy which this new departure involved was that the new service should work quite independently of the existing Oberabschnitte (Upper sections), which would confine themselves to their normal SD functions. In their place it was proposed to set up the so-called Blockstollen (block tunnel) to act as the focal points from which the envisaged espionage activities could be directed. In point of fact only three such Blockstollen were created-at Hof under Hans Christian Daufeldt (later to become Gruppenleiter (group leader) VID), at Tilsit under Heinz Graefe (later Gruppenleiter VIC), and at Vienna under Hastuf (captain) Groebl (later employed by Amt (Office) VI as its representative in Switzerland and subsequently in Rome). But even these three Blockstellen had been set up only in the face of considerable opposition from the Leiter of the SD- Oberabschnitte, who 
regarded themselves as the proper channel for SD reports, irrespective of the extended scope of the, new stations. The Blockstellen were not destined by the subsequent course of events to have a long history, but they played an important part in the events leading up to the creation of Amt (Office) VI.

It was Werner Goettsch who acted as the intermediary between the Foreign Office and Jozef Tiso in accordance with the plan previously conceived by Ribbentrop for the political crisis. The information received through the Blockatlle (Bloc cat) at Hof, where Daufeldt had been working in collaboration with Sturbanfü hrer (major) Hermann Rossner a special assignment, showed that by February 1936 a more active participation by the Germans was possible. Werner Goettsch and Oswald Kraus operated under the orders of the Foreign Office, while and whole enterprise was directed form Vienna where Walter Stahlecker had become Leiter. Goetsch and SS-Standartenführer (colonel) Dr. Edmund Veesenmayer now established contact with the Slovaks themselves, and it was Goettsch to whom Tiso send his letter addressed to Hitler requesting German intervention in order to maintain Slovak independence. Apart from the SD, the incident is of note as it represents one of the very few occasion on which Ribbentrop not only asked for the help of the SD, but took the advice it offered. The same measure of collaboration between the Foreign Office and the SD was singularly lacking after the creation of Amt VI in 1939.

\section{The Position at the Outbreak of war}

The creation of the RSHA coincided almost with the outbreak of hostilities; Heydrich now assumed command of the Gestapo, the Kripo (Criminal Investigation Department) and the SD-Hauptamt, which services now became separate ammeter of the new organization. This major change was the opportune moment for creating the new Ausland's nachrichtendienst (Foreign intelligence services) based on Jost's Abteilung III/3, the new service becoming Amt (Office) VI. The creation of Amt VI was in fact a recognition of the work of Amt III in the preceding year; the security functions of Amt III in the new Amt TV and Amt VI became an offensive and not a defensive service.

The General Position in the Early Stages: It will be appreciated from the account given in Part 1 that of the new Grupped formed under Amt VI that dealing with SouthEastern Europe was in the most favorable position for beginning the new tasks anointed to: the Landergruppen dealing with the far East ,the Near East, Western Europe, and the western Hemisphere, had virtually to begin from scratch, while the Gruppe responsible for the Balkan had the advantage of experience in the type or a certain amount of experience in the work, and, probably most important of all, the territory which it had to exploit lent itself to exploitation in view of the active subversive groups already in existence in the Balkan States. The General effect of this position was that while the other Laendergruppen of Amt $\mathrm{v} 1$ in the early stages spent the first months of their existence in efforts to estabilish a suitable working basis, work in the Balkans continued under the original impetus of previous SD-Leitabschnitt (leading section) Vienna. This previous activity had now to conform itself to the general organization of Amt VI with the installation of the directing Gruppe in Berlin and the dispatch of special representatives to the various countries-For a time in the Balkans the two systems worked together side by side, the SDLeitabschnitt Vienna pursuing its former activity side by side with the creation of the central office in Berlin. 2. Organizational Changes: Referat: VI D1 Hungary and Slovakia Hastuf Karl Hanke VI D2 Iugoslavia VI D3 Roumania Oberstürmbannfuhrer (1t. colonel) Wilhelm Wanek VI D4 Bulgaria and Greece Ostuf Ernst Langlotz VI D5 Turkey and Near East 
Hastuf Walter Hagen It will be noted that in this organization Gruppe VI D was also competent for Turkey and the Near East. The Amt was reorganized in 1941 when Gruppe VI E was renamed V (groupe Leader) I B with Stubaf Hermman Rossner and Gruppenleiter, and the Referent including such officers as Stubaf Waneck, Stubaf Goettsch, Stubaf Wilhelm Beissner, Hastuf Hoettl, Hastuf Groebl, and Hauptsturmführer Otto von Bolschwing. Details of the breakdown of this Gruppe VI $\mathrm{B}$ are backing, but it is known that Gruppe was still responsible for Turkey and the Near East.

Comparison of the personnel in the period 1939-41 with those still working under VI $E$ at the end shows that the Gruppes maintained a remarkable degree of continuity of personnel.

As a result, for the personal interest of Kaltenbrunner in the work of the Gruppe, $6 \mathrm{E}$ developed a working basis which differs from the normal functioning of the other Laendergruppen, a tendency which became more marked after the transfer of the central office from Berlin to Viena late in 1943. A liaison officer only remained in Berlin. The final structure of the Gruppe and the leading personnel, was established in 1943 and this was the final organization that the work of the Gruppe in the Balkan States. The Gruppe maintained liaison officers which the Neubacher and Altenberg Dienststellen (Department), these liaison officers being directly subordinated to the to the Gruppenleiter. In common with other Laendergruppen each had a Referat with a referent an user whose duty it was to act as the collecting point of information within the Referat, but who in VI E also acted as liaison officer with the outside offices, with which he kept in personal contact, and an Auswerter (analyst) responsible for the evaluation and dissemination of information. In addition, there were subordinate Sachbearbeiter working under their direction. The Referate conducted their operation through the
Hauptbeauftragte (chief Comissioner) working in the various countries under suitable cover.

The outside organization of Gruppe $6 \mathrm{E}$ took two forms, as in addition to the Hauptbeauftragte, the Gruppe also had representatives in the various $\mathrm{BdS}$ (counterespionage) set up in the countries of South-Eastern Europe at different times. The BdS normally had a small Abteilung 6 under the control of a Sachbearbeiter (clerk) if the territory controlled by the BdS was important enough to warrant it. The BdS himself worked more closely liaison with Amt VI than was the case, for instance, in Western Europe, were the Bds normally showed himself uncooperative and unsympathetic to Amt 6 work. The reason of course lay in the relatively much stronger position of 6 E in South-Eastern Europe.

\section{Channels of Communication}

The normal means of communication was of course by $\mathrm{W} / \mathrm{T}$, but after the transfer to Vienna, the other common channel used was the couriers of the Lufthansa. The Hauptbeauftragte were also required to visit the central office at least once every two months in order to submit special reports and to attend conferences under the Gruppenleiter, and occasionally under Schellenberg. Likewise, the Referent also paid frequent visits to the outstations to make personal contact with them?

The liaison by Gruppe $6 \mathrm{E}$ with other agencies operating in the countries within the control of the Gruppe was also much closer than in other Laendergruppen. The reason for this cooperation lay in the strength of Gruppe $6 \mathrm{E}$ itself. The tendency was especially marked in the case of the Foreign Office, Ribbentrop though this was not due to any official policy laid down by Ribbentrop, but to the personal relationships established with the Foreign Office representatives themselves. Another important close relationship between Kaltenbbruner and Neubacher of the foreign office, who had been active whit 
Kaltenbbruner in Austria in the days prior to the Anschluss.

\section{Gruppe 3 B of Amt 3}

In territory occupied by German forces Amt 3 maintained its interest through Gruppe 3 $B$ which was responsible for the supervision of German minority groups in South-Eastern Europe. The spheres of interest between $6 \mathrm{E}$ and $3 \mathrm{~B}$ of course overlapped, and $6 \mathrm{E}$ was responsible for passing to $3 \mathrm{~B}$ information concerning such minority groups without giving details of its own intelligence activities within these groups. The most prominent minority groups operating in South-Eastern Europe were the Andreas Group in Roumania, the Janko group in Serbia, the Altoayer group in Croatia, the Basch group in Hungary, and the Karmasin group in Slovakia.

Similarly, there was much closer cooperation between $6 \mathrm{E}$ and $6 \mathrm{~S}$ than existed between $6 \mathrm{~S}$ and the other Laendergruppen of Amt 6, liaison which had two fundamental causes. This rules applied to Leitstelle 2 Sud-Ost for similar reasons. Official liaison was maintained through the person of Hastuf Gerhard Muller Mandal, who in December in 1944 was given the special appointment of Referent $6 \mathrm{E} / \mathrm{S}$, in which capacity he acted as liaison officer for Gruppe $6 \mathrm{E}$ to Skorzeny. In the latter stages too Roland Gunne in Roumania was responsible for sabotage operations in that country in cooperation with Dienststelle 3000 under Begus.

The liaison with Neubacher, who acted as special Foreign Office representative in the Balkans, was a close one, and was due in the first instance to the close association which had existed between Neubacher and Kaltenbrunner in pre-war days in Austria. Kaltenbrunner had a high opinion of Neubacher 's ability and knowledge on Balkan affairs, and the policy was laid down by Kaltenbbruner himself that $6 \mathrm{E}$ should cooperate fully with Neubacher, irrespective of the attitude of Ribbentrop.
The relations between Ribbentrop and Neubacher were not cordial, as the former was jealous of the Foreign Office in Romania, and by 1942 had been given the appointment of special envoy and plenipotentiary in South-Eastern Europe whit the special assignment of dealing with partisan activities in Greece, establishing contact with Draza Mihailovic in Jugoslavia, and suppressing communist the Balkans.

\section{The Romanian Crisis}

In August 1944 Christescu, the head of the Romanian Secret Service, reported to Amt VI on the impending crisis in Romania. Eugen Christescu also established contact with Manfred von Killinger, the Foreign Office representative, and warned him of the possibility of Romania 's defection from the war, but the Foreign Office refused to take the reports seriously. The actual defection there for a took the German government by surprise, and hurried arrangements were made to take counter measures. It was Dienststelle Altenberg. Altenberg had been the Foreign Office representative in Greece until his retirement from that country in November 1943. In September 1944 Altenberg was given the assignment of creating a Dienststelle whose special function was liaison with the various exiled Balkan governments, the Stelle having its seat in Vienna itself, where it remained until early April 1945. The Dienststelle consisted of some eighteen people and had its own w/t set. Altenberg was responsible for recruitment of volunteer legions of Bulgarians and Romanians in Germany, and for their ideological training. Contact between $6 \mathrm{E}$ and the Dienststelle was not so strong as that with Dienststelle Neubacher. Nevertheless, the Stelle was a source of information to $6 \mathrm{E}$, to which organization it passed its reports based on information obtained from prisoners and persons crossing into Austria from the Balkans. Hastuf Zeischka was appointed as official 
liaison officer between the two organizations. Scandinavia and Italy being dealt with under two Gruppen to with them latterly belonged.

\section{The Role of Gruppe $6 \mathrm{E}$ in the Final Stages}

The tendencies which were noticeable by 1944 became more market in the early part of 1945 when the situation became more averse to Germany. Resistance as symbolized by the activities of Gruppe VI S Otto Skorzeny became increasingly important to the biter-enders Gruppen $6 \mathrm{~B}$ and $6 \mathrm{D}$, and to a lesser extent $6 \mathrm{C}$, had become largely ineffective, and Schellenberg was new natively engaged in opening up lines of approach to the Western Allies. Gruppe $6 \mathrm{E}$, the only Laendergruppe to liaise effectively with $6 \mathrm{~S}$, was however meeting with growing threat the Gruppe was able to maintain its networks, with however a purpose in view. Gruppe $6 \mathrm{E}$ left Vienna in March, evacuating in turn to Steyerling, to Kremsmuster, and finally to Alt Aussee. Now two lines of development emerged. Kaltenbrunner and Skorzeny still actively pursued their Redoubt plans for continued while VI E became independent in independent approaches to the Western Powers with a view maintaining its own organization intact.

As early as 1943 SS-Sturmbannführer, Wilhelm Höttl had been actively engaged in making contact with those circles in Austria favoring the independence of Austria from Germany. This contact with the Austrian Freedom Movement had not been without Kaltenbrunner knowledge, who indeed encouraged it. But, whereas Hoettl had the conception of developing these contacts with a view to obtaining for Austria some degrees of favorable treatment when the inevitable end came, Kaltenbrunner, a confirmed 'bitter-ender' who did not depart from his conception of a Gross-Deutschland with its center of political gravity in the South-East rather than in Berlin, regarded the maneuver merely as a penetration of opposition groups within Germany. By
March 1945, when the situation was rapidly deteriorating, the first approach to the Allies was made by Hoettl - an approach of which Kaltenbruner was aware, though he instructed that it should be made to order to obtain information only, and not with a view to any commitment on the part of Germany. [1] Hoettl worked for Kaltenbrunner and Himmler and had their protection at all time. He was influential in Hungarian making policy because of his backing. He made everything in his power to prevent Szalasi and his Arrow cross party to gaining access to power. [2]

Kaltenbrunner meantime left Berlin at the end of April armed with authority granted by Himmler to act as plenipotentiary for Austria, and was responsible for all future resistance in that area, an ambition realized, though rather late in the day. The split in Amt 6 now became complete; learning that Walter Schellenberg in the North was already arranging this surrender to the Allies through Sweden, Kaltenbrunner dismissed him from office, and in the subsequent reorganization of the Amt, appointment Waneck as Amt Chef 6 and Skorzeny as Chef of the millitary Amt. The Austrian Group were now in full command, and with Kaltenbrunner officially recognize as plenipotentiary for Austria, the Triumph of the Austrian Group was now complete. Events however proved too much for Kaltenbrunner the rapid advance of the Allies into the Redoubt area made any plans for continued resistance invalid, and some sort of compromise between the 'bitterenders' and the $6 \mathrm{E}$ approaches became necessary, the compromise being Kaltenbrunner's 'Austrian Solution'.

\section{Arrests of Gruppe VI E}

Most of the leading personalities of Gruppe VI E have already been arrested and the Gruppe can be considered as effectively liquidated. While, however, information on the structure, personalities and working of VI E is fairly complete, the Special Agencies are still interested in more 
detailed information on the activities of the Gruppe within the Balkan countries themselves, for which purpose special briefs may be submitted from time to time. The War Room however does not require anything more than notification of the arrest of any other leading characters. [1]

After the war Hoettl cooperated with CIC Army of the USA in the framework of the network Mount Vernon. This network was described generally as a network of Austrian informants operating in the Russian occupied zone of Austria who are charged with reporting all information that would be of value to the US Armed Forces. Their mission was penetration of the KPOe Comitee (Communist Party of Austria) the KPOe itself, the Cominform and all other Communist organizations, espionage of all soviet activities to include industrial, information, scientific and military. American secret services evaluation about Hoettl was: during the period he has been in contact with CIC, he has proven to be an excellent source of ideas and he evaluated incoming reports on the Soviets with complete accuracy [3].

\section{Conclusions}

Gruppe VI formed under Amt VI that dealing with South-Eastern Europe was in the most favorable position for beginning the new tasks anointed to: the Landergruppen dealing with the far East ,the Near East, Western Europe, and the western Hemisphere, had virtually to begin from scratch, while the Gruppe responsible for the Balkan had the advantage of experience in the type or a certain amount of experience in the work, and, probably most important of all, the territory which it had to exploit lent itself to exploitation in view of the active subversive groups already in existence in the Balkan States. Gruppe, 6E developed a working basis which differs from the normal functioning of the other Laendergruppen, a tendency which became more marked after the transfer of the central office from Berlin to Vienna in 1943. Gruppe 6 E left Vienna in March, evacuating in turn to Steyerling, to Kremsmuster, and finally to Alt Aussee. At the end of the war most of the leading personalities of Gruppe VI E have been arrested and the Gruppe can be considered as effectively liquidated. Some of the officer worked for the American Secret Services.

\section{References}

[1] Public Record Ofice, Kew Gardens, KV 3/101, A MI5 Report from 9.11.1945.

[2] Hoettl Wilhelm vol 3-0061.pdf.

[3] https://www.cia.gov/library/readingroom/docs/ARMY\%20CIC $\% 20$ NETS $\% 20 \mathrm{IN} \% 20 \mathrm{E}$ ASTERN\%20EUROPE 0002.pdf accessed 12 ${ }^{\text {th }}$ April 2017

[4] Army CIC NETS IN EASTERN EUROPE_0002pdf. specialCollection/nwcda8/192/ARMY CIC NETS IN EASTERN EUROPE/ARMY CIC NETS IN EASTERN EUROPE_0002.pdf accessed 12 ${ }^{\text {th }}$ April 2017 